\title{
FÖRHÅLLANDET MELLAN UPPFATTNINGAR, PERCEPTION OCH PRODUKTION I SVENSKAN I HELSINGFORS
}

\section{Sarah Wikner, Åbo Akademi/Svenska litteratursällskapet i Finland}

I föreliggande artikel studerar jag förhållandet mellan människors uppfattningar, perception och produktion, när det gäller två språkdrag i svenskan i Helsingfors, nämligen konsonantförlängning (t.ex. [ba:k:a]) och vokalförlängning i kombination med finalt r-bortfall (t.ex. [ta:la:]). Syftet är dels att undersöka i vilken mån folkdialektologiska intervjuer kan användas för att få en bild av människors faktiska produktion av enskilda språkdrag, dels att studera hur variationen av konsonantförlängning och vokalförlängning i kombination med finalt $r$-bortfall tar sig uttryck i materialet och diskutera förhållandet mellan uppfattningar, perception och produktion när det gäller just dessa drag. Materialet består av intervjuer och perceptionstest med 40 informanter från Helsingfors med omnejd.

Resultaten visar att uppfattningar, perception och produktion generellt stämmer bra överens på individnivå vad gäller de informanter som uttryckte uppfattningar om konsonantförlängning och/eller vokalförlängning vid r-bortfall i intervjun eller perceptionstestet. Ungefär hälften av informanterna nämnde emellertid inte dragen i intervjun eller perceptionstestet, men bland dessa fanns det ändå sådana som själva hade dragen i sitt språk. Sålunda fanns det inget samband mellan huruvida informanterna uttryckte uppfattningar om dragen eller inte och deras produktion.

Generellt visar resultaten på värdet av att använda olika metoder, undersöka olika aspekter av den språkliga variationen och relatera dem till varandra för att få en helhetsbild och en djupare förståelse för dynamiken i variationen.

Nyckelord: folkdialektologi, Helsingforssvenska, konsonantförlängning, r-bortfall, språklig variation, vokalförlängning

\section{INLEDNING OCH SYFTE}

Inom den folkdialektologiska forskningstraditionen intresserar man sig för hur "vanliga språkbrukare", dvs. personer som inte har

\footnotetext{
Kirjoittajan yhteystiedot:

Sarah Wikner

Jeppaksenhaka 52

02400 Kirkkonummi

sarah.wikner@abo.fi
}

lingvistisk utbildning, uppfattar språklig variation. Grundtanken är att dessa uppfattningar är viktiga att ta i beaktande vid beskrivningen av olika språkliga fenomen och man tänker sig att de i bästa fall kan tillföra språkvetenskapen nya perspektiv och en djupare förståelse för språkhållandena och dynamiken i variationen (Niedzielski \& Preston, 2000, s. 324; Preston, 1999, s. xxiv-xxv).

Inom folkdialektologin har man hittills huvudsakligen fokuserat på att undersöka män- 
niskors mentala dialektkartor, deras förmåga att känna igen och placera olika varieteter geografiskt och/eller deras attityder till olika sätt att tala (se t.ex. Long \& Preston, 2002; Preston, 1999, för exempel på den här typen av studier). Inte sällan har man använt begreppet language awareness, språklig medvetenhet, när man syftat på människors förmåga att uppfatta språklig variation och identifiera olika varieteter och enskilda språkdrag (t.ex. Preston, 1996, s. 40-41). Då har informanternas uppfattningar och perception i regel studerats i förhållande till lingvisters motsvarande beskrivningar, inte i förhållande till informanternas eget språkbruk. Studier som handlar om förhållandet mellan informanters uppfattningar, perception och produktion är förvånansvärt få, istället har man huvudsakligen fokuserat på att undersöka uppfattningar, perception och produktion var för sig (Fowler \& Galantucci, 2006, s. 633). Dessutom kan man konstatera att de studier som gjorts huvudsakligen har fokuserat på hur informanter uppfattar enskilda språkdrag i olika typer av perceptionstest, där forskarna på förhand har bestämt vilka språkdrag som ska studeras (t.ex. Fridland \& Kendall, 2012; Johnstone \& Kielsing, 2008; Sumner \& Samuel, 2009). Mer sällan har man undersökt hur sådana uppfattningar som informanter spontant ger uttryck för i en intervju och spontant reagerar på ett i perceptionstest, utan att intervjuaren eller testledaren explicit frågar efter särskilda reaktioner, förhåller sig till deras produktion. Inte heller har man i någon större utsträckning undersökt hur informanters uppfattningar om olika språkdrag, dvs. deras mentala representationer av dem, förhåller sig till deras faktiska perception (jfr Clopper \& Pisoni, 2006, s. 316).

Många av de folkdialektologiska studier som hittills gjorts har fokuserat på gruppgenomsnitt och resultaten har följaktligen generaliserats till att gälla alla medlemmar av en viss grupp, t.ex. beroende påålder, regional härkomst och/eller socialgruppstillhörighet (t.ex. Demirci, 2002; L'Eplattenier-Saugy, 2002; Moreno Fernández \& Moreno Fernández, 2002; Williams m.fl., 1999). Det betyder alltså att man i regel inte har beaktat en eventuell variation på individnivå, men som Barbara Johnstone och Scott Kiesling (2008, s. 12) påpekar, är det snarast mycket sannolikt att också människor inom samma "grupp" tillskriver olika språkdrag varierande betydelser och använder dem på olika sätt (se även t.ex. Coupland, 2007; Eckert, 2008; Maegaard, 2014; Mendoza-Denton, 2004 för kritiska diskussioner om den traditionella variationsanalysens kvantitativa metoder och gruppkategoriseringar).

Med den här artikeln vill jag bidra med en individorienterad undersökning inom det folkdialektologiska fältet. Syftet är att studera förhållandet mellan uppfattningar, perception och produktion på individnivå när det gäller två språkdrag i svenskan i Helsingfors i Finland, nämligen konsonantförlängning och vokalförlängning i kombination med finalt r-bortfall (se kapitel 2 för en noggrannare beskrivning av språkdragen och bakgrunden till att just dessa drag står i fokus). Min undersökning skiljer sig från tidigare studier på området, eftersom jag har börjat med att studera informanternas uppfattningar och perception och dessutom låtit uppfattningarna vara avgörande för vad jag över huvud taget ska undersöka i faktisk produktion, medan de flesta tidigare studier istället har börjat med att undersöka informanternas produktion av på förhand bestämda drag och först därefter försökt förklara variationen genom att undersöka deras uppfattningar och/eller perception (se t.ex. Fridland \& Kendall, 2012; Johnstone \& Kiesling, 2008; Rabb, u.u.). Medan tidigare studier har utgått från produktionen utgår jag alltså istället från uppfattningarna. I metodiskt hänseende är mitt 
syfte att undersöka i vilken mån folkdialektologiska intervjuer kan användas för att få en bild av människors faktiska produktion av enskilda språkdrag. Specifikt koncentrerar jag mig på konsonantförlängning och vokalförlängning i kombination med finalt r-bortfall i svenskan i Helsingfors. Ett ytterligare syfte är sålunda att undersöka hur variationen av de här dragen tar sig uttryck i mitt intervjumaterial och diskutera eventuella samband mellan uppfattningar, perception och produktion när det gäller just dessa drag.

Med uppfattningar avser jag i denna artikel informanternas mentala bild av, syn på och förståelse för ett språkligt fenomen, medan jag med perception syftar på deras förmåga att höra skillnad mellan och identifiera olika varieteter och varianter av språkdrag. Med produktion avser jag informanternas verkliga användning av ett visst språkdrag.

Artikeln är disponerad så att jag i följande kapitel börjar med att presentera bakgrunden till den här studien och valet av undersökta drag närmare. Därefter, i kapitel 3, redogör jag för mina teoretisk-metodiska utgångspunkter och tidigare forskning. I kapitel 4 presenterar jag mitt material och min analysmetod och i kapitel 5 redogör jag för mina resultat. I kapitel 6 diskuterar jag resultaten.

\section{BAKGRUND TILL VALET AV SPRÅKDRAG}

Ett språkdrag som ofta brukar förknippas med Helsingfors är konsonantfölängning (Haapamäki \& Wikner, 2015; Leinonen, 2013, 2015; Reuter, 1982, 2014; Wikner, 2014). Med benämningen konsonantförlängning avser jag i denna artikel ett uttal med lång vokal och (över)lång konsonant i segmentföljden lång vokal plus tonlös konsonant i betonad stavelse, så att t.ex. prata, köpa och visa uttalas [pra:t:a], [tjö:p:a] och [vi:s:a]. I grunden handlar det emellertid om förhållandet mel- lan vokalens och konsonantens varaktighet (se Leinonen, 2015, s. 168 ff). I [pra:ta] är vokalen längre än konsonanten, medan vokaloch konsonantkvantiteten i [pra:t:a] närmar sig varandra. I [pra:t:a] är konsonanten alltså längre än i [pra:ta], och detta är sannolikt orsaken till att man i tidigare forskning har använt benämningen konsonantförlängning för detta fenomen (Reuter, 1982).

Mikael Reuter (1982) har undersökt konsonantförlängning i ett socialt skiktat material som samlats in på 1970- och 1980-talen i Helsingfors och han konstaterade att draget var karakteristiskt för personer från högre socialgrupp. Therese Leinonen (2015) har studerat kvantitet i ett nyare material från Helsingfors, Åbo, Vasa och Mariehamn och hennes studie kan därför ses som en uppföljning av Reuters. Vad gäller Helsingfors visar hennes undersökning på liknande resultat, dvs. att konsonantförlängning är vanligare bland högutbildade än lågutbildade personer. En jämförelse städerna emellan visar att konsonantförlängning är klart vanligast i Helsingfors och bland äldre personer i Åbo ${ }^{1}$.

Ett annat språkdrag som inte sällan brukar förknippas med Helsingfors är finalt r-bortfall i kombination med förlängd slutvokal i verbens presensformer och substantivens pluralformer, så att t.ex.jag talar blir [ja ta:la:] och två stolar blir [två sto:la:] (Nyholm, 1984; Reuter, 2014; Stenberg-Sirén, 2014; Wikner, 2014). Det bör framhållas att finalt r-bortfall förekommer överallt i det finlandssvenska språkområdet, särskilt framför ord

\footnotetext{
1 Leinonen använder inte benämningen konsonantförlängning, utan hon skriver om förhållandet mellan vokal- och konsonantkvantitet i V:C-sekvenser (alltså segmentföljden lång vokal plus tonlös konsonant). Jag är medveten om att konsonantförlängning är en förenklad benämning för det kvantitetsfenomen som undersöks i den här artikeln. Eftersom fokus i den här studien ligger på huruvida informanterna har varianten $\mathrm{V}: \mathrm{C}$ : i sitt språk, snarare än $\mathrm{V}: \mathrm{C}$, har jag ändå valt att använda benämningen konsonantförlängning.
} 
som inleds med konsonant (Nyholm, 1984; Wiik, 2002). I vanligt talspråk uttalas r-ljudet därtill ofta approximantiskt, särskilt efter obetonad vokal, vilket i många fall kan uppfattas som ett bortfall (Kuronen, 2006). Det drag som står i fokus i den här studien är alltså snarast en tydlig förlängning av slutvokalen vid finalt $r$-bortfall och inte finalt $r$-bortfall i sig. Det är ett drag som inte tidigare har undersökts i särskilt stor utsträckning. En orsak till det har möjligen att göra med svårigheten att bedöma r-ljudet/r-bortfallet och särskilt en eventuell vokalförlängning till följd av ett bortfall (se avsnitt 4.3 för en vidare diskussion om detta).

Leif Nyholm (1984) har undersökt finalt r-bortfall i verbens presensformer och substantivens pluralformer som en del av en större studie om olika fonologiska och morfologiska variabler i Helsingfors. Han konstaterade att r-bortfall var en allmän företeelse i Helsingfors. Särskilt vanligt var det bland yngre personer, män och personer med arbetarbakgrund.

Orsaken till att jag har valt att studera förhållandet mellan uppfattningar, perception och produktion när det gäller just ovan nämnda drag grundar sig på två tidigare folkdialektologiska studier som jag har gjort, där det har framkommit att människor tenderar att uppfatta dragen som index för svenskan i Helsingfors, eller åtminstone som index för olika sociala stilar, som i sin ur förknippas med Helsingfors (se Haapamäki \& Wikner, 2015; Wikner, 2014).

I Wikner (2014) undersökte jag hur 40 personer i olika åldrar från Helsingfors med omnejd uppfattade sitt eget språk och svenskan i Helsingfors generellt. Jag var bl.a. intresserad av att ta reda på vilka språkdrag de uppfattade som typiska för svenskan i Helsingfors och huruvida de uppfattade en språklig variation inom staden. Jag gjorde intervjuer, där informanterna fick svara på frågor som "Hur skulle du beskriva ditt eget språk?", "Tycker du att svenskan i Helsingfors har några särskilda kännetecken?" och "Tycker du att alla i Helsingfors talar på samma sätt?”. Jag frågade aldrig explicit efter enskilda språkdrag, utan lät informanterna själva lyfta fram de språkdrag som de ansåg vara relevanta i sammanhanget. Det resulterade i att ungefär hälften av informanterna inte nämnde några särskilda språkdrag över huvud taget ${ }^{2}$. Den andra hälften lyfte fram konsonantförlängning och/ eller vokalförlängning vid r-bortfall som typiska drag för sitt eget språk, vissa grupper av människor (i Helsingfors) eller svenskan i Helsingfors generellt.

I en annan studie undersökte jag tillsammans med Saara Haapamäki huruvida 121 informanter (varav 52 från Helsingfors med omnejd) kunde känna igen och placera olika standardnära varieteter geografiskt samt vad de byggde sina omdömen på (se Haapamäki \& Wikner, 2015). Vi använde oss av ett perceptionstest som bestod av talprov av sex talare, varav två var från Helsingfors och resten från andra städer i Finland. Talproven bestod av spontant tal. Talarna hade fătt som uppgift att fritt berätta om sina morgonrutiner i ett par minuter och varje inspelning redigerades sedan till en 30 sekunders sekvens. Eftersom ett av syftena med studien var att ta reda på vilka språkdrag informanterna reagerar på och eventuellt identifierar som kännetecknande för olika städer hade vi alltså inte på förhand bestämt vilka språkdrag som skulle förekomma på talproven. Informanterna fick lyssna på alla talprov två gånger och deras uppgift var att fundera på varifrån talarna kunde komma och varför. Inte heller i detta

\footnotetext{
2 Orsaken till att så många informanter inte lyfte fram några språkdrag över huvud taget har bl.a. att göra med att de över lag uppfattade sitt eget språk som någon form av standardfinlandssvenska. I den meningen ansåg de också att deras eget språk (och svenskan i Helsingfors generellt) saknar utmärkande drag.
} 
sammanhang tvingade vi informanterna att ge en viss typ av svar, utan vi lät dem resonera fritt och ge sådana svar de själva ville och/eller var förmögna till. Undersökningen visade att informanterna över lag hade svårt för att placera talarna geografiskt. Talproven från Helsingfors placerades emellertid oftare rätt än de andra. I dessa fall kunde informanterna (oavsett varifrån de själva kom) ofta identifiera konsonantförlängning och/eller vokalförlängning vid r-bortfall, som de alltså uppfattade som kännetecken för svenskan i Helsingfors.

\section{TEORETISK-METODISKA UTGÅNGSPUNKTER OCH TIDIGARE FORSKNING}

I den här artikeln kombinerar jag folkdialektologi med sociolingvistisk variationsanalys, i och med att informanternas uppfattningar om och perception av konsonantförlängning och vokalförlängning vid r-bortfall jämförs med deras faktiska användning av samma drag. Min folkdialektologiska utgångspunkt innebär att jag ser språkbrukarnas egna uppfattningar om både sitt eget språk och språklig variation generellt som värdefulla och viktiga att ta i beaktande vid studiet av språklig variation (t.ex. Niedzielski \& Preston, 2000, s. 324; Preston, 1999, s. xxiv-xxv). Människors egna uppfattningar ger oss inte bara information om vad enskilda språkdrag och olika varieteter har för betydelse för dem, utan de torde också vara ett värdefullt verktyg för att förstå deras eget språkbruk och variationen av olika språkdrag, t.ex. inom ett visst område eller mellan olika grupper av människor.

Valerie Fridland och Tyler Kendall (2012) har undersökt förhållandet mellan perception och produktion när det gäller några vokalljud i amerikansk engelska. I deras studie deltog 32 personer från tre olika regioner i USA. Informanterna blev först inspelade när de läste några givna meningar, som innehöll de vokalljud som stod i fokus, varefter de utförde ett perceptionstest, där de utifrån givna alternativ skulle välja vilka vokalljud de hörde. Undersökningen visade att det fanns individuella skillnader inom alla regioner, både vad gäller perception och produktion, men också att det fanns ett samband mellan den enskilda individens perception och produktion. En av Fridland och Kendalls (2012, s. 791-792) slutsatser är att en individs perception dels påverkas av de varianter som hen själv producerar, dels av de varianter hen hör i sin omgivning, som medlem av sociala nätverk på olika nivåer. Produktionen påverkas i sin tur av hur individen uppfattar och tolkar de olika varianterna, vilka betydelser hen tillskriver dem och vem hen vill vara eller utge sig för att vara i olika gruppkonstellationer.

Också Johnstone och Kiesling (2008) har kommit fram till liknande resultat. De har undersökt förhållandet mellan uppfattningar, perception och produktion vad gäller monoftongering av /aw/ i engelskan i Pittsburgh ${ }^{3}$. Studien visade att de informanter som uppfattade monoftongeringen som ett lokalt drag sällan hade draget i sitt eget språk, medan de informanter som hade draget i sitt eget språk i regel inte uppfattade det som ett lokalt drag. De informanter som inte hörde skillnad mellan de olika varianterna i ett perceptionstest var i sin tur ungefär lika benägna att ha draget i sitt eget språk som att inte ha det. Allt detta kan enligt Johnstone och Kiesling (2008, s. 23 ff) förklaras utgående från vilka betydelser de enskilda informanterna tillskriver monoftongeringen, något som i sin tur är beroende av deras personliga erfarenheter: vilka människor de umgås med, vilken utbildning och vilka personliga intressen de har, vilka språkliga normer och sociala förhållanden som var

\footnotetext{
3 Monoftongering av /aw/ i engelskan innebär att t.ex. "house" uttalas [ha:s].
} 
gällande när de växte upp osv. En person som av olika orsaker uppfattar ett språkdrag som index för ett visst område, men som samtidigt anser att det är stereotypiskt och eventuellt har negativa attityder till det, har rimligtvis inte draget i sitt eget språk. En person som i första hand tillskriver samma språkdrag olika positiva innebörder kan åandra sidan mycket väl ha draget i sitt eget språk.

Resultaten i ovan nämnda studier antyder alltså att ett kvalitativt individperspektiv är att föredra om man i grunden vill förstå hur, och framför allt varför, människors uppfattningar, perception och produktion påverkas av varandra. Johnstone och Kiesling (2008, s. $25 \mathrm{ff}$ ) förespråkar i detta sammanhang ett fenomenologiskt angreppssätt. De menar att vi dels bör utgå från ett individperspektiv och noggrant undersöka enskilda informanters uppfattningar och personliga erfarenheter, t.ex. med hjälp av intervjuer, dels kartlägga den historiska kontexten och undersöka vilken betydelse den har i sammanhanget. Rune Røsstad (2009), som har undersökt människors dialektuppfattningar i fyra kommuner i Norge, är av samma åsikt. Hans undersökning visar att människors uppfattningar om språklig variation ytterst påverkas av deras sociala orientering, deras personliga erfarenheter och egenskaper, men också av rådande samhälleliga strukturer och normer.

Studier som granskar människors självrapporterade användning av olika språkdrag i förhållande till deras faktiska produktion är i nuläget rätt få. Människors självrapporterade användning har förvisso undersökts, men då har självrapporteringen i regel inte jämförts med deras faktiska produktion. Det här gäller framför allt sådana äldre studier som använt sig av den traditionella dialektologins frågelistmetod för att kartlägga olika varieteters särart och i dessa fall har man i allmänhet även utgått från att den självrapporterade användningen motsvarar det faktiska språk- bruket (jfr Chambers \& Trudgill, 1998, s. $21 \mathrm{ff})$. Som exempel på en nyare studie där ett slags frågelistmetod används kan man nämna Viveca Rabbs (2007) undersökning om genuskongruens i Kvevlaxdialekten. Rabb (2007, s. 91) framhåller förvisso att hennes studie gäller självrapporteringen i sig och att hon inte utgår från att resultaten nödvändigtvis stämmer överens med informanternas faktiska produktion.

Ett exempel på en studie om hur självrapporterad användning förhåller sig till faktisk produktion är Karen Margarethe Pedersens (1991) undersökning om dialekten på Langeland i Danmark. Hennes resultat visar att informanterna i regel talade mindre dialektalt än vad de uppgav sig göra på basis av den frågelista hon hade använt. Pedersen analyserar dock informanternas produktion utgående från ett samtal med henne själv, dvs. en främmande person som inte talar deras dialekt. Pedersen menar således att det är sannolikt att informanternas språk i hemmiljö bättre motsvarar deras självrapportering. Hennes slutsats är att självrapportering mycket väl kan användas för att få en bild av hur dialektalt en person talar, men att den naturligtvis aldrig kan vara exakt. Hon menar också att självrapporteringen torde fungera bäst gällande sådana utpräglade språkdrag som informanterna även diskuterar och funderar över i sin vardag utan att bli tillfrågade om dem, till skillnad från sådana mindre tydliga särdrag som en forskare har valt att fråga om.

Även Johanna Vaattovaaras (2009) studie visar på liknande tendenser. Hon har undersökt gymnasiestuderandes självrapporterade användning av h i icke-initiala stavelser i finskan i Pello i Tornedalen ${ }^{4}$, bl.a. i relation till deras faktiska användning. Hennes undersökning visar att den rapporterade användningen

\footnotetext{
T.ex. lähethäänkö saubnaan för lähdetäänkö saunaan, ungefär 'ska vi bada bastu'.
} 
stämde väl överens med den faktiska, i varje fall gällande sådana språkdrag som är etablerade och stabila i dialekten. Men vad gäller sådana språkdrag som befinner sig i någon slags förändringsprocess, och vars användning därför varierar bland dialekttalarna, motsvarade informanternas självrapportering och faktiska användning varandra inte i lika hög grad. I sådana fall tenderade informanterna att överrapportera den variant som de uppfattade som mest prestigefylld.

\section{MATERIAL OCH ANALYSMETOD}

\subsection{Intervjuer och perceptionstest}

Mitt material består av intervjuer och perceptionstest. Intervjuerna används dels för att undersöka informanternas uppfattningar om konsonantförlängning och vokalförlängning vid r-bortfall, dels för att studera deras produktion av samma drag. Perceptionstestet används i sin tur för att undersöka huruvida informanterna identifierar dragen på inspelade talprov och för att studera förhållandet mellan uppfattningar och perception. Intervjuupplägget och perceptionstestet har kortfattat beskrivits i avsnitt $2^{5}$. Vad gäller intervjun kan man gärna tillägga att den inte enbart handlade om informanternas språkuppfattningar, utan att varje intervju inleddes med frågor om informanternas bakgrund, sociala kontaktnät, vardagliga mobilitet och kännedom om platser i Helsingfors och Finland. Den här informationen har varit viktig för tolkningen av uppfattningarna. Det är också den här delen av intervjun som i första hand används för analysen av informanternas produktion av konsonantförlängning och vokalförlängning vid r-bortfall. Materialet samlades in under åren 2013 och 2014. Jag har

5 Se Wikner (2014) för en närmare beskrivning av intervjuerna och Haapamäki och Wikner (2015) för en närmare redogörelse av perceptionstestet. gjort alla intervjuer själv och fungerat som testledare i alla perceptionstest.

\subsection{Informanter}

Informanterna i den här studien består av 40 personer i olika åldrar från Helsingfors med omnejd. Det är delvis fråga om samma informanter som deltog i Wikner (2014). Av informanterna har 16 endast deltagit i intervjun, medan 24 har deltagit både i intervjun och i perceptionstestet. Intervjun gjordes alltid före testet. De sistnämnda informanterna ingår i delanalysen om förhållandet mellan uppfattningar och perception (avsnitt 5.2). I delanalyserna om informanternas uppfattningar (avsnitt 5.1) och förhållandet mellan uppfattningar och produktion (avsnitt 5.3) ingår alla informanter.

Av informanterna är 28 kvinnor och 12 män. Åldern varierar mellan 17 och 73 år. Åldersfördelningen är dock ojämn i och med att merparten av informanterna, 22 personer, är under 30 år gamla. Elva informanter är mellan 30 och 50 år gamla, medan sju informanter är äldre än 50 år. Informanternas exakta åldrar framgår i tabellerna i resultatredovisningen. Eftersom analysen hela tiden sker på individnivå torde den ojämna ålders- och könsfördelningen dock inte vara ett problem. Bland informanterna finns 31 enspråkigt svenska och 9 tvåspråkiga (svenska-finska) personer. Alla informanter har bott största delen av sitt liv inom Helsingforsregionen ${ }^{6}$.

\subsection{Analysmetod}

Informanternas uppfattningar om och självrapporterade användning av konsonantför-

\footnotetext{
6 Med Helsingforsregionen avser jag i denna artikel Helsingfors och de omkringliggande städerna Esbo, Grankulla och Vanda. Se Wikner (2014, s. 122-123) för en noggrannare beskrivning av informanternas bakgrund och hur informanterna har kontaktats.
} 
längning och vokalförlängning i kombination med finalt r-bortfall har jag analyserat genom att inledningsvis transkribera intervjuerna i transkriptionsprogrammet Transcriber och excerpera alla utsagor som har att göra med något av dragen. Utsagorna har jag analyserat och kategoriserat tematiskt för att se vilka olika typer av uppfattningar som finns och vilka eventuella mönster som går att urskilja. Informanternas uppfattningar presenteras i avsnitt 5.1.

Informanternas perception har jag analyserat genom att studera huruvida de identifierar konsonantförlängning och vokalförlängning vid r-bortfall på talproven i perceptionstestet. Jag har lyssnat igenom de inspelade diskussioner som informanterna för i samband med perceptionstesten mycket noggrant upprepade gånger och gjort anteckningar. Jag har transkriberat och excerperat de utsagor där informanterna påtalar och diskuterar något av dragen och jag har noterat huruvida en identifikation av dragen leder till en korrekt geografisk placering av talproven från Helsingfors eller inte. De uppfattningar som kommer till uttryck i perceptionstestet, samt informanternas eventulla identifikation av dragen, har jag jämfört med de uppfattningar som de ger uttryck för i intervjuerna. Förhållandet mellan uppfattningar och perception diskuteras i avsnitt 5.2.

Analysen av informanternas produktion har jag utfört på följande sätt: Vad gäller konsonantförlängning har jag excerperat de 50 första beläggen på segmentföljden tonlös konsonant efter lång betonad vokal i varje intervju och bedömt dessa med avseende på vokal- och konsonantkvantiteternas längd. Vad gäller vokalförlängning i kombination med finalt r-bortfall har jag excerperat de 30 första beläggen på första och andra konjugationens verb i presens och de 20 första beläggen på första, andra och tredje deklinationens substantiv i plural, dvs. sammanlagt 50 belägg.
Jag har alltså excerperat både förekomster och nollförekomster av dragen och för varje informant beräknat den procentuella fördelningen. Orsaken till att jag excerperade de 50 första beläggen, och inte påbörjade excerperingen t.ex. i mitten av intervjun, är att intervjun inleddes med frågor om informanternas bakgrund, dvs. med sådana ämnen som informanterna torde ha haft lätt att prata om. Senare i intervjun ställde jag frågor om informanternas språkuppfattningar och jag ville så långt som möjligt undvika att använda den här delen av intervjun för en språklig analys. Det lyckades emellertid inte helt, eftersom alla informanter inte uppvisade 50 belägg på variablerna under den första delen av intervjun. De yttranden där informanterna uttryckligen talar om konsonantförlängning eller vokalförlängning vid finalt $r$-bortfall har i varje fall inte excerperats för analysen.

Det säger sig självt att det inte är någon lätt uppgift att avgöra huruvida en informant har konsonantförlängning och/eller vokalförlängning vid r-bortfall eller inte. Man torde dock inte kunna komma över problematiken på något annat sätt än genom upprepade väldigt noggranna genomlyssningar av materialet. Att göra fonetiska mätningar hade i detta fall inte varit möjligt pga. det bakgrundsljud som finns på vissa av inspelningarna. Det bör även framhållas att instrumentella analyser inte alltid stämmer överens med det intryck man får av vokal-och konsonantkvantiteterna som lyssnare. Reuter (1982, s. 68) talar om "det subjektiva kvantitetsintrycket", som han menar att också påverkas av vokalens längd och tillslutningen mellan vokal och konsonant. Det påverkas dessutom av taltempot och den språkliga kontexten (Vainio, 2001, s. 24-25, jfr även Leinonen, 2015, s. 192). Sålunda ansåg jag att en auditiv bedömning av vokal- och konsonantkvantiteterna i mitt fall var mest lämplig. Man kan förstås inte komma ifrån att "det subjektiva kvantitetsintrycket" 
i detta fall är just mitt intryck och det är naturligtvis möjligt att en annan forskare (t.ex. med en annan språklig bakgrund ${ }^{7}$ ) hade gjort andra bedömningar. Reuter (1982, s. 75) påpekar dock att det viktigaste är att forskarens egna bedömningar är sinsemellan jämförbara.

Förhållandet mellan informanternas uppfattningar och produktion har studerats genom en kvalitativ jämförelse av uppfattningarna och den procentuella andelen förekomster och icke-förekomster av variablerna på individnivå. På gruppnivå har jagjämfört produktionen bland de informanter som nämner dragen $i$ intervjun eller perceptionstestet med produktionen bland de informanter som inte nämner dragen. Jag har dels räknat ett medeltal för andelen förekomster inom respektive grupp, dels beaktat spridningen inom grupperna. De resultat som gäller produktionen och förhållandet mellan uppfattningar och produktion presenteras i avsnitt 5.3.

\section{RESULTATREDOVISNING}

\subsection{Uppfattningar om \\ konsonantförlängning och vokalförlängning i kombination med finalt $r$-bortfall}

Tidigare folkdialektologisk forskning har visat att icke-lingvister över lag har svårt för att spontant lyfta fram specifika språkdrag i olika varieteter (t.ex. Bolfek Radovani, 2000; Palander, 2011, s. 167; Wikner, 2014, s. 129). Bland mina informanter finns det 16 som inte nämner vare sig konsonantförlängning eller vokalförlängning i kombination med finalt $\mathrm{r}$-bortfall i intervjuerna. De nämner i regel

\footnotetext{
Jag är själv uppväxt och bosatt i Kyrkslätt, en kommun som ligger ca $30 \mathrm{~km}$ väster om Helsingfors. Jag anser att jag talar en sydfinländsk standardvarietet, såsom också mina föräldrar. Enligt min egen bedömning karakteriseras mitt språk inte av de drag som står i fokus i den här artikeln.
}

inte något annat drag heller. En av orsakerna till det är att majoriteten av dessa informanter uppfattar sin egen varietet och svenskan i Helsingfors som ett slags standardfinlandssvenska och i den meningen anser de att den inte har några utmärkande drag. Det är naturligtivs också möjligt att en del informanter är oförmögna att beskriva dragen eller inte kom att tänka på något utmärkande språkdrag i intervjusituationen. I så fall betyder det förstås inte att informanterna helt saknar uppfattningar om olika språkdrag och möjligen kunde alternativa intervjufrågor och andra formuleringar ha triggat fram andra svar. I dessa fall fyller emellertid perceptionstestet en viktig funktion, eftersom informanterna där hade möjlighet att reagera på talstimuli.

Bland informanterna finns det endast sju som nämner både konsonantförlängning och vokalförlängning vid r-bortfall. Sex informanter nämner endast konsonantförlängning och elva informanter nämner endast vokalförlängning vid $\mathrm{r}$-bortfall. Sammanlagt finns det alltså 13 informanter som nämner konsonantförlängning och 18 informanter som nämner vokalförlängning vid r-bortfall. Nedan koncentrerar jag mig på de 24 informanter som nämner dragen eller något $\mathrm{av}$ dragen i intervjuerna. Jag redogör för informanternas uppfattningar i tabellform. I tabell 1 presenteras informanternas uppfattningar om konsonantförlängning $(\mathrm{KF})$ och i tabell 2 presenteras deras uppfattningar om vokalförlängning $\mathrm{i}$ kombination med finalt $\mathrm{r}$-bortfall (VR). Tabellerna kommer att fungera som utgångspunkt vid analysen av förhållandet mellan uppfattningar, perception och produktion i avsnitt 5.2 och 5.3 . 
Tabell 1. Informanternas uppfattningar om konsonantförlängning (KF). Totalt 13 informanter.

\begin{tabular}{|c|c|c|}
\hline Uppfattning & Attityd & Självrapporterad användning \\
\hline $\begin{array}{l}\text { (A) KF är allmänt förekommande } \\
\text { i Helsingfors(regionen). Draget } \\
\text { uppfattas i regel som den normenliga } \\
\text { varianten. } \\
\text { Totalt } 6 \text { inf. }\end{array}$ & $\begin{array}{l}\text { KF uppfattas } \\
\text { som neutralt; } \\
\text { det frambringar } \\
\text { inga särskilda } \\
\text { attityder. }\end{array}$ & $\begin{array}{l}\text { Tre inf. säger att KF } \\
\text { kännetecknar deras eget } \\
\text { språk, medan tre är något } \\
\text { osäkra på sin användning. } \\
\text { En av de sistnämnda säger } \\
\text { att användningen beror på } \\
\text { vem hon talar med. }\end{array}$ \\
\hline $\begin{array}{l}\text { (B) KF förknippas med hög } \\
\text { bildningsnivå, prestige och/eller en } \\
\text { "gammal, fin" helsingforsiska. Draget } \\
\text { uppfattas som den normenliga } \\
\text { varianten och informanterna } \\
\text { nämner i regel inte KF i sig, utan } \\
\text { den avvikande varianten (dvs. långa } \\
\text { vokalkvantiteter). } \\
\text { Totalt } 4 \text { inf. }\end{array}$ & $\begin{array}{l}\text { KF uppfattas som } \\
\text { neutralt/ } \\
\text { positivt. }\end{array}$ & $\begin{array}{l}\text { Två inf. säger att de har } \\
\text { KF själva, medan två säger } \\
\text { att draget inte finns i } \\
\text { deras eget språk. }\end{array}$ \\
\hline $\begin{array}{l}\text { (C) KF uppfattas som ett } \\
\text { överklassdrag, det förknippas med } \\
\text { ett arrogant och högfärdigt beteende. } \\
\text { Det uppfattas inte som normenligt. } \\
\text { Totalt } 3 \text { inf. }\end{array}$ & $\begin{array}{l}\text { KF uppfattas } \\
\text { som negativt; } \\
\text { det framkallar } \\
\text { negativa } \\
\text { attityder. }\end{array}$ & $\begin{array}{l}\text { Alla inf. säger att de inte } \\
\text { har KF själva. }\end{array}$ \\
\hline
\end{tabular}

Tabell 2. Informanternas uppfattningar om vokalförlängning vid r-bortfall (VR). Totalt 18 informanter.

\begin{tabular}{|c|c|c|}
\hline Uppfattning & Attityd & Självrapporterad användning \\
\hline $\begin{array}{l}\text { (D) VR är allmänt förekommande } \\
\text { i Helsingfors(regionen). Däremot } \\
\text { uppfattas det inte som normenligt } \\
\text { (jfr uppfattning A; KF uppfattas som } \\
\text { normenligt). } \\
\text { Totalt } 7 \text { inf. }\end{array}$ & $\begin{array}{l}\text { VR uppfattas } \\
\text { som neutralt; } \\
\text { det frambringar } \\
\text { inga särskilda } \\
\text { attityder. }\end{array}$ & $\begin{array}{l}\text { Fyra inf. säger att de } \\
\text { har draget själva, två är } \\
\text { osäkra och en säger att } \\
\text { han inte har draget. }\end{array}$ \\
\hline $\begin{array}{l}\text { (E) VR är typiskt för ungdomsspråket } \\
\text { i Helsingfors(regionen). En del } \\
\text { uppfattar VR som ovårdat och } \\
\text { slentrianmässigt. } \\
\text { Totalt } 8 \text { inf. }\end{array}$ & $\begin{array}{l}\text { VR frambringar } \\
\text { i regel inga } \\
\text { särskilda } \\
\text { attityder, ett } \\
\text { par inf. ser det } \\
\text { som negativt. }\end{array}$ & $\begin{array}{l}\text { Sju inf. säger att de inte } \\
\text { har draget själva. En inf. } \\
\text { säger att draget finns i } \\
\text { hennes eget språk. }\end{array}$ \\
\hline $\begin{array}{l}\text { (F) VR förknippas med ett arrogant } \\
\text { och högfärdigt beteende. Däremot } \\
\text { uppfattas det inte som ett } \\
\text { överklassdrag (jfr uppfattning C; KF } \\
\text { uppfattas som ett överklassdrag). } \\
\text { Totalt } 3 \text { inf. }\end{array}$ & $\begin{array}{l}\text { VR frambringar } \\
\text { negativa } \\
\text { attityder. }\end{array}$ & $\begin{array}{l}\text { Alla inf. säger att de inte } \\
\text { har draget själva. }\end{array}$ \\
\hline
\end{tabular}

Variationen i uppfattningarna verkar inte entydigt kunna förklaras med hänsyn till utomspråkliga faktorer. Ålder kan möjligen ha en viss betydelse. Merparten av de informanter som ser konsonantförlängning som ett neutralt drag i Helsingfors(regionen) 
(uppfattning A) är i 20-års åldern, medan de som uppfattar draget som prestigefyllt (uppfattning B) är 50 år eller äldre. Alla de informanter som menar att vokalförlängning vid r-bortfall är allmänt förekommande i Helsingfors(regionen) (uppfattning D) är vidare under 25 år gamla, medan de flesta av dem som anser att draget snarast är typiskt för ungdomsspråket (uppfattning E) är över 45 år.

Det finns sju informanter som nämner både konsonantförlängning och vokalförlängning vid r-bortfall i intervjuerna. Nedan diskuterar jag hur uppfattningarna om de olika dragen förhåller sig till varandra. Förhållandet presenteras i tabell 3. Informantkoderna i tabellen anger informantens kön (K/M) och födelseår. I en del av informantkoderna ingår dessutom en bokstav; den skiljer åt informanter av samma kön som är födda samma år. Informanterna är uppställda i tabellen enligt sina uppfattningar. Versalerna står för vilken typ av uppfattning informanterna har (se tabell 1 och 2).

Tabell 3. Uppfattningar om KF och VR i förhållande till varandra.

\begin{tabular}{|l|l|l|}
\hline Informant & $\begin{array}{l}\text { Uppfattning } \\
\text { om KF }\end{array}$ & $\begin{array}{l}\text { Uppfattning } \\
\text { om VR }\end{array}$ \\
\hline K96h & A & D \\
\hline K90 & A & D \\
\hline K89a & A & D \\
\hline K46 & B & E \\
\hline K44 & B & E \\
\hline K87b & C & F \\
\hline K96i & C & D \\
\hline
\end{tabular}

I tabellen framgår att det finns ett visst samband mellan informanternas uppfattningar om konsonantförlängning å ena sidan och deras uppfattningar om vokalförlängning vid r-bortfall å andra sidan. De informanter som anser att konsonantförlängning är ett allmänt förekommande och neutralt drag i Helsing- fors (uppfattning A) tycker att vokalförlängning vid r-bortfall också är det (uppfattning D). De två äldre informanter (K46, K44) som tycker att konsonantförlängning är ett prestigefyllt drag i positiv bemärkelse (uppfattning B) anser samtidigt att vokalförlängning vid r-bortfall snarast kännetecknar ett sorts ovårdat ungdomsspråk (uppfattning E). En av de informanter som förknippar konsonantförlängning med ett arrogant beteende (K87, uppfattning C) har liknande negativa attityder mot vokalförlängning vid r-bortfall (uppfattning F). Den andra informanten som har negativa attityder mot konsonantförlängningen (K96i, uppfattning C) anser dock att vokalförlängning vid r-bortfall är ett allmänt fenomen i Helsingfors (uppfattning D).

Detta tyder på att konsonantförlängning och vokalförlängning vid r-bortfall ofta är sammankopplade eller beroende av varandra $\mathrm{i}$ informanternas mentala bilder av den språkliga variationen i Helsingfors. Antingen uppfattas båda dragen som kännetecknande för svenskan i Helsingfors i allmänhet eller som kännetecknande för en viss social och stereotypisk stil, eller också uppfattas dragen som särskiljande, så att det ena (konsonantförlängning) kännetecknar ett prestigefyllt språk, medan det andra (vokalförlängning vid r-bortfall) kännetecknar ett slags ungdomsspråk.

\subsection{Förhållandet mellan uppfattningar och percpetion}

I det här avsnittet fokuserar jag på de 24 informanter som har deltagit både i intervjun och $\mathrm{i}$ perceptionstestet. Resultaten presenteras i tabell 4. Bokstäverna i parenteserna anger vilken typ av uppfattning om språkdragen informanterna ger uttryck för i intervjuerna (se tabell 1 och 2). Informanterna är uppställda i tabellen enligt sina uppfattningar. 
Tabell 4. Uppfattningar i förhållande till perception.

\begin{tabular}{|c|c|c|c|c|c|}
\hline Informant & $\begin{array}{l}\text { Nämner } \\
\text { KF i intervjun } \\
\text { (uppfattning) }\end{array}$ & $\begin{array}{l}\text { Identifierar KF } \\
\text { i testet }\end{array}$ & $\begin{array}{l}\text { Nämner VR } \\
\text { i intervjun } \\
\text { (uppfattning) }\end{array}$ & $\begin{array}{l}\text { Identifierar } \\
\text { VR i testet }\end{array}$ & $\begin{array}{l}\text { Korrekta } \\
\text { placeringar av } \\
\text { talproven från } \\
\text { Helsingfors }\end{array}$ \\
\hline K96d & $x(A)$ & $x$ & - & - & $2 / 2$ \\
\hline K96h & $x(A)$ & $x$ & $x(D)$ & - & $2 / 2$ \\
\hline K90 & $x(A)$ & $x$ & $x(D)$ & $x$ & $2 / 2$ \\
\hline K89a & $x(A)$ & $x$ & $x(D)$ & - & $2 / 2$ \\
\hline M44 & $x(A)$ & - & - & - & $0 / 2$ \\
\hline K44 & $x(B)$ & $x$ & $x(E)$ & - & $2 / 2$ \\
\hline K96i & $x(C)$ & $x$ & $x(D)$ & $x$ & $2 / 2$ \\
\hline K65 & $x(C)$ & $x$ & - & - & $2 / 2$ \\
\hline M96b & - & $x$ & $x(D)$ & - & $1 / 2$ \\
\hline K89b & - & $x$ & $x(E)$ & $x$ & $2 / 2$ \\
\hline M69 & - & $x$ & $x(E)$ & - & $2 / 2$ \\
\hline K96b & - & $x$ & - & - & $2 / 2$ \\
\hline M94b & - & $x$ & - & - & $2 / 2$ \\
\hline K96a & - & - & - & - & $1 / 2$ \\
\hline K96c & - & - & - & - & $0 / 2$ \\
\hline K96f & - & - & - & - & $1 / 2$ \\
\hline $\mathrm{K} 96 \mathrm{~g}$ & - & - & - & - & $2 / 2$ \\
\hline M96a & - & - & - & - & $0 / 2$ \\
\hline K95 & - & - & - & - & $0 / 2$ \\
\hline M95 & - & - & - & - & $0 / 2$ \\
\hline M94a & - & - & - & - & $0 / 2$ \\
\hline M75 & - & - & - & - & $0 / 2$ \\
\hline K63 & - & - & - & - & $2 / 2$ \\
\hline M46 & - & - & - & - & $2 / 2$ \\
\hline
\end{tabular}

De uppfattningar som informanterna uttrycker i intervjun stämmer bra överens med de uppfattningar som kommer till uttryck i perceptionstestet. Det finns m.a.o. inga informanter som skulle uppvisa motstridiga uppfattningar i intervjun och perceptionstestet. De informanter som nämner konsonantförlängning i intervjun identifierar i regel även draget i testet. Det finns bara en informant (M44) som inte gör det. Det finns fem informanter som inte nämner konsonantförlängning $\mathrm{i}$ intervjun, men som ändå fäster sig vid det i testet. Det verkar alltså som om dessa informanter inte kom att tänka på språkdraget $\mathrm{i}$ intervjusituationen, trots att de på basis av perceptionstestet har uppfattningar om det. Elva informanter nämner inte alls konsonantförlängning, varken i intervjun eller perceptionstestet. Majoriteten av dem anser att både de själva och talarna på talproven från Helsingfors talar en form av finlandssvensk standardsvenska som saknar särdrag.

Endast tre av de åtta informanter som nämner vokalförlängning vid $r$-bortfall i intervjuerna identifierar det också i testet. På det hela taget identifierar alltså informanterna konsonantförlängning i högre grad än vokalförlängning vid r-bortfall. En förklaring till det kan givetvis vara att konsonantförlängning förekommer fler gånger på talproven i testet än vokalförlängning vid r-bortfall. Det är emellertid viktigt att påpeka att det inte alltid är 
helt entydigt huruvida informanterna i sina beskrivningar avser konsonantförlängning, vokalförlängning vid r-bortfall eller båda. Flera informanter använder ordet [pra:t:a:] som exempel, vilket skulle kunna syfta både på konsonantförlängning och vokalförlängning vid r-bortfall. När jag frågade de här informanterna om de kunde förklara vad de menar lite närmare gällde förklaringen dock oftast bara endera draget. Informanternas sätt att beskriva dragen på både i intervjun och $\mathrm{i}$ perceptionstestet tyder i alla fall på att konsonantförlängning och vokalförlängning vid r-bortfall i många fall uppfattas som tätt sammankopplade.

I tabell 4 framgår vidare att de informanter som i perceptionstestet har identifierat konsonantförlängning och/eller vokalförlängning vid r-bortfall i regel har placerat båda talproven från Helsingfors rätt. Det finns bara en informant (M96b) som endast har placerat det ena talprovet rätt. Av de tio informanter som inte identifierar något av dragen i perceptionstestet är det sju som inte har placerat något talprov rätt, två som har placerat ett rätt och tre som har placerat två rätt. De sistnämnda informanterna motiverar dock inte sina geografiska placeringar på något sätt, utan svaren verkar vara rena gissningar. En rimlig slutsats är alltså att då informanter identifierar olika språkdrag (som enligt dem fungerar som index för en viss region) i ett perceptionstest, är sannolikheten för att de också kan placera talprovet geografiskt större, än då informanter inte identifierar några språkdrag över huvud taget. Vidare verkar sannolikheten för att informanter identifierar olika språkdrag i ett perceptionstest vara större i sådana fall då de också har tydliga mentala representationer av språkdragen, i den meningen att de spontant väljer att lyfta fram dem i en intervju, än i sådana fall då de inte spontant uttrycker några åsikter om dem (i en intervju). Vilka människor som har den här typen av men- tala representationer, förmåga att känna igen enskilda språkdrag och höra skillnad mellan olika varieteter är förstås en annan fråga. De mentala representationerna och perceptionen verkar åtminstone inte ha något att göra med kön eller ålder. Tidigare forskning har visat att människors uppfattningar om språklig variation och deras förmåga att känna igen olika varieteter dels beror på personliga erfarenheter av olika sätt att tala, dels på individuella egenskaper (t.ex. Clopper, 2004; Clopper \& Pisoni, 2006; Haapamäki \& Wikner, 2015; Palander, 2011; Preston, 1993; Williams m.fl., 1999).

Ytterligare en aspekt är i detta sammanhang värd att noteras, nämligen informanternas uppfattningar om språkdragens sociala betydelser i förhållande till deras perception. Som framgår av tabellen verkar typ av uppfattning inte ha någon betydelse för huruvida informanterna identifierar konsonantförlängning i testet eller huruvida de placerar talproven från Helsingfors rätt. Det man ändå kan notera är att de informanter (K96i, K65) som har negativa attityder mot konsonantförlängningen (uppfattning C) är mycket säkra på sina svar i perceptionstestet, medan de övriga i regel är något mer tvekande.

\subsection{Förhållandet mellan uppfattningar och produktion}

I detta avsnitt presenteras förhållandet mellan informanternas uppfattningar och produktion. Eftersom analysen sker på individnivå har jag valt att presentera resultaten i en tabell, där man kan se hur varje enskild individ uppfattar och producerar dragen. Informanterna är uppställda i tabellen utgående från deras produktion av konsonantförlängning; de som har förhållandevis störst användning finns högst upp. Bokstäverna i kolumnerna som anger informanternas uppfattningar syftar på vilken typ av uppfattning informanterna 
har om dragen (se tabell 1 och 2). I kolumnen som gäller informanternas uppfattningar om konsonantförlängning har en del bokstäver markerats med en asterisk $\left({ }^{*}\right)$. Den anger att informanten inte har nämnt konsonantförlängning $i$ intervjun, utan endast i perceptionstestet.

Tabell 5. Produktion i förhållande till uppfattning.

\begin{tabular}{|c|c|c|c|c|}
\hline Informant & \begin{tabular}{|l|} 
Produktion \\
av KF \\
(i procent) \\
\end{tabular} & \begin{tabular}{|l|} 
Uppfattning om KF \\
(i intervjun och/eller \\
perceptionstestet)
\end{tabular} & \begin{tabular}{|l|} 
Produktion \\
av VR (i procent)
\end{tabular} & $\begin{array}{l}\text { Uppfattning om VR } \\
\text { (i intervjun och/eller } \\
\text { perceptionstestet) }\end{array}$ \\
\hline K96c & $97 \%$ & & $9 \%$ & . \\
\hline M94b & $97 \%$ & $A^{*}$ & $8 \%$ & . \\
\hline K91 & $90 \%$ & . & $10 \%$ & $\mathrm{D}$ \\
\hline M94a & $88 \%$ & . & $8 \%$ &. \\
\hline M75 & $88 \%$ & . & $0 \%$ & . \\
\hline M69 & $88 \%$ & $A^{*}$ & $0 \%$ & $\mathrm{E}$ \\
\hline K95a & $86 \%$ &. & $12 \%$ & . \\
\hline K96a & $84 \%$ &. & $8 \%$ & . \\
\hline K89b & $80 \%$ & $A^{*}$ & $0 \%$ & $E$ \\
\hline K87a & $80 \%$ &. & $0 \%$ & $F$ \\
\hline K79 & $78 \%$ &. & $4 \%$ & $\mathrm{D}$ \\
\hline K90 & $76 \%$ & A & $0 \%$ & $\mathrm{D}$ \\
\hline M95 & $74 \%$ & 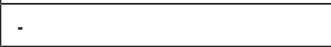 & $0 \%$ & . \\
\hline K73 & $74 \%$ & & $4 \%$ & $E$ \\
\hline K44 & $74 \%$ & $B$ & $0 \%$ & $E$ \\
\hline M73 & $66 \%$ &. & $2 \%$ &. \\
\hline M44 & $58 \%$ & A & $0 \%$ & . \\
\hline K46 & $56 \%$ & $B$ & $0 \%$ & $E$ \\
\hline M96a & $48 \%$ & & $0 \%$ & . \\
\hline M89 & $46 \%$ & . & $0 \%$ & $\mathrm{~F}$ \\
\hline K96d & $44 \%$ & $A$ & $21 \%$ &. \\
\hline K64 & $38 \%$ & . & $0 \%$ & $E$ \\
\hline K63 & $36 \%$ &. & $0 \%$ &. \\
\hline K40 & $22 \%$ & $B$ & $0 \%$ & . \\
\hline K96b & $20 \%$ & $A^{*}$ & $0 \%$ &. \\
\hline K89a & $18 \%$ & A & $2 \%$ & $\mathrm{D}$ \\
\hline M46 & $18 \%$ & . & $0 \%$ & . \\
\hline K54 & $16 \%$ &.- & $0 \%$ & $E$ \\
\hline K47 & $10 \%$ & & $0 \%$ & $E$ \\
\hline K91 & $8 \%$ & $A$ & $0 \%$ & . \\
\hline K96h & $6 \%$ & A & $0 \%$ & D \\
\hline K66 & $6 \%$ & $B$ & $0 \%$ & . \\
\hline K96f & $2 \%$ &. & $0 \%$ &. \\
\hline M96b & $2 \%$ & $A^{*}$ & $0 \%$ & $\mathrm{D}$ \\
\hline K96g & $0 \%$ & 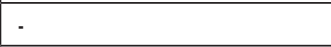 & $0 \%$ &. \\
\hline K96i & $0 \%$ & C & $18 \%$ & $\mathrm{D}$ \\
\hline K87b & $0 \%$ & C & $0 \%$ & $F$ \\
\hline K77 & $0 \%$ &. & $2 \%$ &. \\
\hline M67 & $0 \%$ & . & $0 \%$ & . \\
\hline K65 & $0 \%$ & C & $0 \%$ & . \\
\hline
\end{tabular}


I tabellen framgår inledningsvis att det finns en tämligen stor variation vad gäller produktionen av konsonantförlängning. Det finns inga informanter som uteslutande använder sig av konsonantförlängning. Två informanter har dock en mycket hög andel, $97 \%$, och ytterligare åtta informanter har $80 \%$ eller högre andel. Fem informanter har en andel på 74-78\%. Det betyder alltså att sammanlagt 15 informanter har en andel på minst $74 \%$. Sex informanter uppvisar en rätt stor intraindividuell variation med en andel på 44-66\%. Fyra informanter har en andel på 20-38\%, medan 15 informanter har mindre än $20 \%$. Av de sistnämnda uppvisar sex informanter inga belägg alls. Variationen verkar inte kunna förklaras utgående från sådana utomspråkliga faktorer som jag känner till om informanterna. Bland de informanter som har en hög andel konsonantförlängning finns både män och kvinnor och både äldre och yngre personer. Utbildningsnivå är inte heller avgörande, eftersom alla mina informanter har hög utbildning eller håller på att skaffa sig en sådan. Det man kan notera är att merparten av de informanter som har en låg andel konsonantförlängning i sitt språk säger att de talar någon form av standardfinlandssvenska, medan de som har en hög andel konsonantförlängning oftare säger att de talar Helsingforssvenska.

Som jag redan nämnt uppvisar många informanter en intraindividuell variation vad gäller produktionen av konsonantförlängning. Inom ramen för den här studien har jag dock inte undersökt hur den intraindividuella variationen eventuellt kan förklaras. Vid bedömningen och excerperingen av de olika varianterna har jag inte beaktat faktorer som taltempo, vokalhöjd och fonetisk kontext, men det är sannolikt att den typen av faktorer åtminstone till en del skulle kunna förklara den intraindividuella variationen (jfr Leinonen, 2015, s. 176 ff). Av betydelse är rimligtvis även interaktionella faktorer, som t.ex. emfas.

Vad gäller förhållandet mellan uppfattningar och produktion kan jag börja med att konstatera att de tre informanter (K96i, K87b, K65) som har negativa attityder mot konsonantförlängningen och som förknippar den med ett arrogant och högfärdigt beteende (uppfattning C) inte själva uppvisar några belägg över huvud taget. De som uppfattar draget som allmänt förekommande i Helsingfors (uppfattning A) och de som förknippar draget med ett vårdat och prestigefyllt språk $\mathrm{i}$ positiv bemärkelse (uppfattning B) har emellertid konsonantförlängning i sitt eget språk i mycket varierande grad, mellan 2 och $97 \%$. Om man går närmare in på informanternas uppfattningar på individnivå och även tar i beaktande vad de säger om sin egen produktion stämmer uppfattningar och produktion i regel ändå bra överens. De informanter som har en andel på 44 \% eller mer säger i intervjun (eller perceptionstestet) att de har konsonantförlängning själva (informanterna M94b, M69, K89b, K90, K44, M44, K46 och K96d). De informanter som har en andel på $22 \%$ eller mindre säger å andra sidan att de inte har draget i sitt eget språk (informanterna K40, K96b, K89a, K91, K96h, K66 och M96b).

Vad gäller de 18 informanter som nämner konsonantförlängning i intervjun eller perceptionstestet stämmer alltså uppfattningar, självrapporterad användning och produktion bra överens på individnivå. Variationen i produktion inom gruppen är dock stor. Ytterligheterna är 0 och $97 \%$ och gruppmedeltalet är $36 \%$. Variationen i produktion bland de 22 informanter som inte nämner konsonantförlängning i intervjun eller perceptionstestet är lika stor, 0-97\%, men gruppmedeltalet är något högre, 50 \%. I genomsnitt förekommer alltså konsonantförlängning oftare bland de informanter som inte nämner draget i inter- 
vjun eller perceptionstestet än bland dem som nämner det. Mitt material är naturligtvis för litet för att jag ska kunna dra särskilt långtgående slutsatser utifrån gruppmedeltal. Intressant är i varje fall att en stor del av de informanter som inte nämnde konsonantförlängning i intervjun eller perceptionstestet och som ansåg att deras eget språk saknar utmärkande drag över huvud taget och snarast kan beskrivas som standardfinlandssvenska ändå uppvisar belägg på konsonantförlängning. Som framgår av tabellen har hälften av dem som inte nämnde draget en andel på 66 \% eller mer. Sålunda kunde man tänka sig att dessa informanter uppfattar konsonantförlängningen som en standardvariant och den motsvarande varianten som avvikande och detta är möjligen också orsaken till att de inte nämner draget $i$ intervjun eller perceptionstestet. I och för sig nämner de inte den motsvarande varianten heller.

Jag går nu över till informanternas produktion av vokalförlängning $i$ kombination med finalt r-bortfall. Jag vill börja med att framhålla att finalt $r$-bortfall/ett approximantiskt uttal av finalt -r förekommer hos alla informanter. En tydlig förlängning av slutvokalen $\mathrm{i}$ kombination med finalt r-bortfall är däremot, som framgår av tabell 5 , tämligen sällsynt. Sammanlagt 27 informanter uppvisar inga belägg över huvud taget och fem informanter (K79, K73, M73, K89a, K77) uppvisar endast några enstaka belägg (2-4\%). Åtta informanter (K96c, M94b, K91, M94a, K95a, K96a, K96d och K96i) har en andel på 8-21 \%. De sistnämnda informanterna, de som alltså uppvisar flest belägg, är alla unga. Vid intervjutillfället var en 21 år och resten 17-19 år. Sex av dem är kvinnor och två är män, men eftersom det finns fler kvinnor i materialet som helhet går det inte att dra några slutsatser utifrån detta. Hälften har bott i Helsingfors hela sitt liv, medan de övriga är födda och delvis uppvuxna i städerna omkring Helsingfors (Esbo,
Grankulla, Sibbo), vilket tyder på att draget förekommer bland unga i hela Helsingforsregionen. Också när det gäller de informanter som uppvisar enstaka belägg på vokalförlängning vid $r$-bortfall kan man se en viss koppling till ålder. Alla dessa informanter är födda på 1970- och 1980-talen. Eftersom det är fråga om enstaka belägg är det emellertid svårt att dra några vidare slutsatser.

Hur förhåller sig produktionen av vokalförlängning vid r-bortfall till produktionen av konsonantförlängning? Sex (av åtta) av de informanter som har den högsta andelen vokalförlängning vid r-bortfall (8-21\%) har också en relativt hög andel konsonantförlängning i sitt språk (80-97 \%). Såtillvida verkar det alltså som om produktion av vokalförlängning vid r-bortfall har ett samband med produktion av konsonantförlängning. Det finns emellertid två undantag, nämligen informanterna K96d och K96i. Dessa uppvisar procentuellt sett flest belägg på vokalförlängning vid r-bortfall, $21 \%$ och $18 \%$, men, i jämförelse med de övriga sex som har en andel på $8 \%$ eller mer, minst belägg på konsonantförlängning. K96i uppvisar de facto inga belägg på konsonantförlängning alls och hon har t.o.m. negativa attityder till det. Vokalförlängning vid r-bortfall uppfattar hon däremot som ett allmänt förekommande drag i Helsingforsregionen. Hon säger också att hon har draget själv, liksom alla hennes kompisar. Det avgörande är kanske att K96i är född och delvis uppvuxen i Sibbo. Vid intervjutillfället studerade hon vid en gymnasieskola i Helsingfors och bodde delvis i Sibbo och delvis i Helsingfors. Man kunde eventuellt tänka sig att vokalförlängning vid r-bortfall för hennes del hör till ett slags ungdoms- eller kompisspråk och att användningen av det är ett sätt att passa in i gruppen.

Vad gäller förhållandet mellan uppfattningar om och produktion av vokalförlängning vid r-bortfall kan man notera följande: 
Endast 5 av de 13 informanter som uppvisar belägg på vokalförlängning vid r-bortfall nämner draget i intervjun. Fyra av dessa anser att draget är allmänt förekommande i Helsingforsregionen (uppfattning D) och en att det kännetecknar ungdomsspråket (uppfattning E).

De som har negativa attityder mot vokalförlängning vid r-bortfall (uppfattning F) uppvisar inga belägg. Det samma gäller merparten av dem som anser att draget är kännetecknande för ungdomsspråket (uppfattning E). Av dem som anser att vokalförlängning vid r-bortfall är allmänt förekommande i Helsingfors(regionen) (uppfattning D) finns det fyra som uppvisar belägg och tre som inte gör det. Intressant att notera är att två av de informanter som anser att draget är allmänt förekommande och som även själva säger att de har draget inte uppvisar några belägg på det i intervjun. Eventuellt har detta - och även det faktum att draget över lag är sällsynt i mitt material - att göra med intervjun som samtalskontext. Det är möjligt att informanterna uppfattar intervjun som en tämligen formell samtalssituation, medan vokalförlängning vid r-bortfall främst anses tillhöra informella diskussioner. Trots att jag strävade efter att intervjusituationen skulle vara så ledig som möjligt är det självklart att den inte motsvarar ett vardagligt samtal vänner emellan. En undersökning av vokalförlängning vid r-bortfall i vardagliga samtal skulle därför tillföra viktig information om i vilken mån draget förekommer i Helsingfors(regionen) och vem som använder det. På basis av den här studien verkar det i varje fall som om det i första hand används av yngre personer.

Det finns åtta informanter som uppvisar belägg på vokalförlängning vid r-bortfall, men som inte nämner draget i intervjun eller perceptionstestet. Som jag redan nämnt kan en orsak till det vara att de inte kom att tänka på draget i intervjusituationen. En annan orsak kan vara att de inte uppfattar draget som "avvikande" och inte hör skillnad mellan olika varianter. Det torde i så fall betyda att de inte heller uppfattar det som socialt eller regionalt betydelsefullt.

Om man jämför variationen av vokalförlängning vid r-bortfall på gruppnivå, bland dem som nämner draget i intervjun å ena sidan (18 informanter) och bland dem som inte nämner det å andra sidan (22 informanter), kan man se att variationen är ungefär lika stor inom båda grupperna. Produktionen bland dem som nämner vokalförlängning vid rbortfall är mellan 0 och $18 \%$ (medeltal $2 \%$ ), medan motsvarande siffror bland dem som inte nämner draget är 0 och $21 \%$ (medeltal $3 \%)$. Detta resultat stämmer alltså överens med motsvarande resultat för konsonantförlängning, dvs. att variationen i produktion inte är beroende av huruvida informanterna uttrycker uppfattningar om dragen eller inte.

\section{AVSLUTNING}

Syftet med den här artikeln var tudelat: dels att undersöka i vilken mån folkdialektologiska intervjuer kan användas för att få en bild av människors faktiska produktion av enskilda språkdrag, dels att studera hur variationen av konsonantförlängning och vokalförlängning i kombination med finalt r-bortfall tar sig uttryck i mitt intervjumaterial från Helsingfors och diskutera förhållandet mellan uppfattningar, perception och produktion när det gäller just dessa drag.

Intervjuerna var uppbyggda så att inga frågor om specifika språkdrag ställdes, utan istället hade informanterna möjlighet att själva lyfta fram sådana språkdrag som de spontant kom att tänka på i intervjusituationen som svar på öppna frågor. Det visade sig att ungefär hälften av informanterna inte alls nämnde något språkdrag som de ansåg som utmärkande för sitt eget språk. Den andra hälften 
lyfte fram konsonantförlängning och/eller vokalförlängning $i$ kombination med finalt $\mathrm{r}$ bortfall. För dessa informanteras del stämde uppfattningar, självrapporterad användning, perception och produktion i regel bra överens, i varje fall vad gäller konsonantförlängning. Vad gäller vokalförlängning i kombination med finalt $\mathrm{r}$-bortfall förekom emellertid en viss överrapportering, $i$ och med att en del av de informanter som själva sade att de har draget i sitt språk inte uppvisade särskilt många belägg i intervjun. Över lag var draget sällsynt i mitt material. Som jag redan påpekat kan detta ha att göra med intervjun som samtalskontext, men också med min närvaro som forskare och min egen språkanvändning (jfr Pedersen, 1991). I intervjun strävade jag efter att tala ett ledigt språk. Enligt min egen bedömning använde jag inte själv vokalförlängning vid r-bortfall (eller konsonantförlängning). Särskilt med tanke på att somliga informanter uppfattade draget som något ovårdat och kännetecknande för ungdomsspråket är det möjligt att informanterna försökte undvika draget i intervjun. Det är självklart att den här typen av intervjuer inte motsvarar informella samtalssituationer vänner emellan och att jag på det här sättet inte har kunnat komma åt informanternas vardagsspråk. Vad jag på basis av den här studien i varje fall kan säga är att konsonantförlängning och vokalförlängning vid r-bortfall verkar associeras med olika stilnivåer, i och med att det ena draget förekommer rätt frekvent i intervjun, men inte det andra. Det verkar alltså som om konsonantförlängningen i allmänhet uppfattas som accepterad att använda i en formell intervju, medan vokalförlängning vid r-bortfall snarare verkar anses tillhöra informella diskussioner och ett ledigt vardagsspråk eller ungdomspråk.

Min undersökning har vidare visat att variationen i produktionen var ungefär lika stor bland de informanter som nämnde dragen $\mathrm{i}$ intervjun eller perceptionstestet som bland dem som inte nämnde dem (jfr Johnstone \& Kiesling, 2008). En del av de informanter som inte påtalade dragen i intervjun uppvisade alltså ändå belägg på dem. Att människor inte har spontana kommentarer om enskilda språkdrag betyder sålunda inte att deras eget språk saknar särdrag.

Det kan givetvis finnas flera orsaker till att informanterna inte nämnde språkdragen $\mathrm{i}$ intervjun och en del av dem har jag diskuterat $\mathrm{i}$ samband med resultatredovisningen. Det är emellertid också skäl att diskutera intervjuns upplägg och intervjufrågorna. Man kan naturligtivs inte utesluta att jag med hjälp av explicita frågor om konsonantförlängning och vokalförlängning vid $r$-bortfall eller andra formuleringar av intervjufrågorna hade fått ta del av andra, eller flera, uppfattningar än de som nu kom fram. Inom folkdialektologin har man ofta diskuterat huruvida det alls är möjligt att i grunden komma åt människors uppfattningar på grund av skillnaderna i forskares och lekmäns metalingvistiska kunskap och vikten av att formulera sig på "rätt" sätt har inte sällan diskuterats (t.ex. Mielikäinen \& Palander, 2002, s. 91; Niedzielski \& Preston, 2000, s. 3-10; Teinler, 2016, s. 76-77). $\AA$ andra sidan aktualiseras den här typen av metodologiska frågor i alla slags intervjuer och enligt Nancy Niedzielski och Dennis Preston (2000, s. 3-10) ska problemet inte överdrivas. Att forskares och lekmäns språkliga beskrivningar rör sig på olika detaljnivåer är förstås klart.

Inom ramen för den här studien var jag uttryckligen intresserad av sådana språkdrag som informanterna spontant lyfter fram och jag ville undvika att explicit fråga efter specifika på förhand bestämda drag. Språkdrag som informanter spontant lyfter fram torde vara sådana som de också i tidigare sammanhang har reflekterat över, vilket betyder att de uppfattningar som kommer fram torde 
vara underbyggda och genomtänkta och inte formulerade i intervjusituationen. Att informanterna inte behövde ge snabba svar, utan hade möjlighet att i lugn och ro reflektera över frågorna torde också vara en fördel (jfr Pearce, 2012, s. 7; Røsstad, 2008, s. 28). I detta sammanhang fungerade även perceptionstestet som en kompletterande metod. Talproven i testet fungerade som stimuli och några av de informanter som inte nämnde konsonantförlängning $\mathrm{i}$ intervjun fäste sig vid draget $\mathrm{i}$ testet och uttryckte då uppfattningar om det.

Det faktum att somliga informanter inte nämnde konsonantförlängning eller vokalförlängning vid r-bortfall $i$ intervjun eller perceptionstestet betyder alltså nödvändigtvis inte att de helt saknar uppfattningar om dem men det kan göra det. I så fall kan man tänka sig att informanterna helt enkelt inte fäster sig vid dragen eller inte identifierar de olika varianterna av dragen i vardaglig interaktion och att dragen sålunda saknar relevans för dem (jfr Johnstone \& Kiesling, 2008, s. 24-25; Niedzielski \& Preston, 2000, s. 3-10).

Vad jag sammanfattnignsvis kan konstatera är i varje fall att folkdialektologiska intervjuer mycket väl torde kunna användas för att få en tämligen bra bild av människors produktion av enskilda språkdrag, men det gäller endast i sådana fall då människor har tydliga mentala representationer av språkdragen och uttrycker uppfattningar om dem (jfr Pedersen, 1991; Vaattovaara, 2009). I sådana fall då människor inte uttrycker några uppfattningar går det däremot inte att dra några slutsatser om deras produktion. Motsvarande resultat gäller även för perceptionen. Över lag stämde uppfattningar och perception bra överens: majoriteten av de informanter som nämnde dragen $\mathrm{i}$ intervjun identifierade dem också $\mathrm{i}$ testet, medan största delen av dem som inte nämnde dragen i intervjun inte heller fäste sig vid dem i testet. De som inte identifierade dragen i testet var lika benägna att dem i sitt eget språk som att inte ha dem. En identifikation av dragen i sig sade emellertid ingenting om informanternas egen produktion, men det gjorde den uppfattning de uttryckte i samband med identifikationen.

Generellt visar den här studien på värdet av att använda olika metoder, undersöka olika aspekter av den språkliga variationen och relatera dem till varandra, både för att få en helhetsbild och för att söka förklaringar till variationen (jfr Preston, 2015; Rabb, u.u.; Soukup, 2015). Människors uppfattningar om språkdrags olika betydelser kan ge oss en indikation på hur variationen ser ut i faktisk produktion och därigenom kan uppfattningarna visa på vilka språkdrag som över huvud taget kunde vara intressanta att undersöka närmare i faktisk produktion. Uppfattningarna kan $\mathrm{i}$ vissa fall också förklara variationen (jfr även Rabb, u.u.). De är i grunden beroende av personliga egenskaper, personliga erfarenheter, social orientering och preferenser, de uppstår i interaktion med andra människor (t.ex. Clopper, 2004; Clopper \& Pisoni, 2006; Palander, 2011; Williams et. al., 1999). Det är sannolikt att den här typen av bakgrundsfaktorer i högre grad kan förklara den språkliga variationen än traditionella förklaringskategorier som t.ex. ålder och kön (t.ex. Agha, 2007; Coupland, 2007; Eckert, 2008). Människors uppfattningar om språkdrags olika betydelser kan också bidra med förklaringar till kontextbunden variation. Ett drag som uppfattas som informellt undviks sannolikt i formella situationer, medan drag som anses formella rimligtvis inte påträffas i vardagsspråket. Trots att alla människor inte alltid uttrycker uppfattningar om enskilda språkdrag över huvud taget torde just det också säga någonting om språkdragens karaktär och betydelse för människorna. 


\section{LITTERATUR}

Agha, A. (2007). Language and social relations. Cambridge: Cambridge University Press.

Bolfek Radovani, J. (2000). Attityder till svenska dialekter - en sociodialektologisk undersökning bland vuxna svenskar. FUMS Rapport nr 201. Uppsala: Uppsala universitet.

Chambers. J.K. \& Trudgill, P. (1998). Dialectology. Cambridge: Cambridge University Press.

Clopper, C. (2004). Linguistic Experience and the Perceptual Classification of Dialect Variation. Indiana: Indiana University. Tillgänglig på: http://www.ling.ohio-state.edu/ cclopper/ clopper_thesis.pdf

Clopper, C. \& Pisoni, D. (2006). Perception of Dialect Variation. I: D. Pisoni \& R. Remez (red.), The Handbook of Speech Perception, (s. 313-337). Oxford: Blackwell.

Coupland, N. (2007). Style. Language, variation and identity. Cambridge: Cambridge University Press.

Demirci, M. (2002). Gender differences in the perception of Turkish regional dialects. I: D. Long \& D. Preston (red.), Handbook of perceptual dialectology vol 2 (s. 41-50). Amsterdam: John Benjamins.

Eckert, P. (2008). Variation and the indexical field. Journal of Sociolinguistics, 12, 453-476.

Fridland, V. \& Kendall, T. (2012). Exploring the relationship between production and perception in the mid front vowels of U.S. English, Lingua, 122, 779-793.

Fowler, C. \& Galantucci, B. (2006). The relation of speech perception and speech production. I: D. Pisoni \& R. Remez. (red.), The handbook of speech perception (s. 633-652). Oxford: Blackwell.

Haapamäki, S. \& Wikner, S. (2015). Att undersöka lyssnares perception av regional variation. Folkmålsstudier, 53, 35-77.

Johnstone, B. \& Kiesling, S. (2008). Indexicality and experience: Exploring the meaning of /aw/monopthhongization in Pittsburg. Journal of Sociolinguistics, 12, 5-53.

Kuronen, M. (2006). Uttalet av /r/ i finlandssvenskan. I: P. Ledin m.fl. (red.), Svenskans beskriuning 28 (s. 139-146). Örebro: Örebro universitet.
Leinonen, T. (2013). Phonetic quantity as a social marker in urban Finland Swedish. I: C. Gooskens \& R. Van Bezooijen (red.), Phonetics in Europe (s. 181-204). Frankfurt am Main: Peter Lang.

Leinonen, T. (2015). Talet lever! Fyra studier $i$ svenskt talspråk $i$ Finland. Studier i nordisk filologi 86. Helsingfors: Svenska litteratursällskapet i Finland.

L'Eplattenier-Saugy, C. (2002). A perceptual dialect study of French in Switzerland. I: D. Long \& D. Preston (red.). Handbook of perceptual dialectology vol 2, (s. 351-365). Amsterdam: John Benjamins.

Long, D. \& Preston, D. (2002). Handbook of perceptual dialectology, vol 2. Amsterdam: John Benjamins.

Maegaard, M. (2014). Etnografisk metode i sociolingvistikken. Folkmålsstudier, 52, 57-76.

Mendoza-Denton, N. (2004). Language and identity. I: J. K. Chambers \& P. Trudgill \& N. Schilling-Estes (red.), Handbook of Language Variation and Change, (s. 474-499). Oxford: Blackwell.

Mielikäinen. A. \& Palander. M. (2002). Suomalaisten murreasenteesta. Sananjalka, 44, 86-109.

Moreno Fernández, J. \& Moreno Fernández F. (2002). Madrid perceptions of regional varieties in Spain. I: D. Long \& D. Preston (red.), Handbook of perceptual dialectology vol 2 (s. 295-320). Amsterdam: John Benjamins.

Niedzielski, N. \& Preston, D. (2000). Folk linguistics. Berlin: Mouton de Gruyter.

Nyholm, L. (1984). Svenskt stadsmål i Helsingfors. Helsingfors: Meddelanden från institutionen för nordiska språk och nordisk litteratur vid Helsingfors universitet, serie B, nr 8 .

Palander, M. (2011). Itä- ja eteläsuomalaisten murrekäsitykset. Helsingfors: Suomalaisen kirjallisuuden seura.

Pearce, M. (2012). Folk accounts of dialect differences in Tyne and Wear. Dialectologia et Geolinguistica, 20, 5-25.

Pedersen, K. M. (1991). Selvrapportering - kan det bruges till noget? Danske folkemål, Bind 33, 111-121.

Preston, D. (1993). Folk dialectology. I: D. Preston (red.), American dialect research, (s. 333-378). Philadelphia: John Benjamins. 
Preston, D. (1996). Whaddayaknow. The modes of folk linguistic awareness. Langugage awareness, 5, 40-73.

Preston, D. (1999). Handbook of perceptual dialectology, vol 1. Amsterdam: John Benjamins.

Preston, D. (2015). Does language regard vary? I: Prikhodkine, A. \& Preston, D. (red.), Responses to langugae varieties. Variability, processes and outcomes (s. 3-36). Amsterdam-Philadelphia: John Benjamins.

Rabb, V. (2007). Genuskongruens på reträtt. Variation i nominalfrasen $i$ Kvevlaxdialekten. Åbo: Åbo Akademis förlag.

Rabb, V. (u.u.). Hur varierar Vasasvenskan? En undersökning av Vasabors perception av språklig variation kontrasterad mot deras språkliga produktion. Folkmålsstudier, 55.

Reuter, M. (1982). Kvantitet i Helsingforssvenskan. Helsingfors: Helsingfors universitet.

Reuter, M. (2014). Så ska det låta. Om finlandssvenska och språkriktighet. Helsingfors: Scriptum.

Røsstad. R. (2008). Den spräklege røynda. Ein studie i folkelingvistikk og dialektendring frå austre Vest-Agder. Oslo: Novus.

Røsstad, R. (2009). Foundations of language perceptions and the role of external factors: a Norweigan case. Language Awareness, 18, 96-12.

Soukup, B. (2015). Mixing methods in the study of language attitudes: Theory and application. I: Prikhodkine, A. \& Preston, D. (red.), Responses to language varieties. Variability, processes and outcomes (s. 55-84). Amsterdam-Philadelphia: John Benjamins.
Stenberg-Sirén, J. (2014). Skriftspråksnära talat standardspråk. En studie av uttalsdrag i upplästa finlandssvenska tv- och radionyheter 1970-2009, Språk och stil NF, 24, 197-230.

Summer, M. \& Samuel, A. (2009). The effect of experience on the perception and representation of dialect variants. Journal of Memory and Language, 60, 487-501.

Teinler, J. (2016). Dialekt där den nästan inte finns. En folklingvistisk studie av dialektens sociala betydelse i ett standardspråksnära område. Uppsala: Uppsala universitet.

Vaattovaara, J. (2009). Meän tapa pubua. Tornionlaakso pellolaisnuorten subjektiivisena paikkana ja murrealueena. Helsingfors: Suomalaisen kirjallisuuden seura.

Vainio, M. (2001). Artifical neutral network based on prosody model for Finnish text-to-speech synthesis. Helsingfors: Helsingfors universitet.

Wiik, B. (2002). Studier i de österbottniska dialekternas fonologi och morfologi. Studier i nordisk filologi 80. Skrifter utgivna av Svenska litteratursällskapet i Finland, nr 642, Helsingfors.

Wikner, S. (2014). Svenskan i Helsingfors ur talarnas perspektiv. Puhe ja kieli, 34, 119-137.

Williams, A \& Garrett, P. \& Coupland N. (1999). Dialect recognition. I: D. Preston (red.), Handbook of perceptual dialectology, vol 1 (s. 345-358). Amsterdam: John Benjamins. 


\section{KÄSITYSTEN, HAVAINTOJEN JA KIELENKÄYTÖN VÄLINEN SUHDE} HELSINGISSÄ PUHUTTAVASSA RUOTSISSA

Sarah Wikner, Åbo Akademi/Svenska litteratursällskapet i Finland

Tässä artikkelissa tarkastelen ruotsinkielisten helsinkiläisten käsityksiä ja havaintoja kahdesta kielenpiirteestä sekä näiden käsitysten ja havaintojen suhdetta siihen, miten samat yksilöt käyttävät kyseisiä kielenpiirteitä. Tarkasteltavat piirteet ovat soinnittoman konsonantin keston pidentäminen äänneympäristössä, jossa sitä edeltää pitkä vokaali (esim. [ba:k:a], 'leipoa'), ja vokaalin keston pidentäminen sananloppuisen r:n kadon yhteydessä (esim. [ta:la:], 'puhun'). Tutkimuksen tavoitteena on selvittää kansandialektologisten haastattelujen soveltavuutta, kun halutaan saada kuva siitä, miten tiettyjä kielenpiirteitä todellisuudessa käytetään. Tarkoitus on myös tutkia kielenpiirteiden variaatiota haastattelutilanteessa ja selvittää käsitysten, havaintojen ja käytön välistä suhdetta. Tutkimusaineistona ovat 40 ruotsinkielisen helsinkiläisen haastattelut ja kuuntelutestit.

Tutkimus osoittaa, että haastattelussa tai kuuntelutestissä kielenpiirteitä mainitsevien informanttien käsityksillä ja havainnoilla on yksilötasolla yhteys siihen, miten he käyttävät tutkittuja kielenpiirteitä haastattelutilanteessa. Toisaalta noin puolet haastateltavista ei mainitse tutkimuksen kohteena olevia kielenpiirteitä lainkaan. Haastattelussa osa heistä kuitenkin käytti näitä piirteitä itse. Tämä osoittaa, ettei kielenpiirteiden käyttö ole riippuvaista siitä, onko informanteilla niistä mentaalisia representaatioita vai ei.

Kaiken kaikkiaan tutkimus korostaa erilaisten metodien yhdistämistä, variaation tutkimista erilaisista näkökulmista ja näiden näkökulmien suhteuttamista toisiinsa. Näin voidaan saada syvällisempi käsitys kielen vaihtelun dynamiikasta.

Avainsanat: Helsingin ruotsi, kansandialektologia, kielen vaihtelu, konsonantin keston pidentäminen, sananloppuisen r:n kato, vokaalin keston pidentäminen 


\section{THE RELATIONSHIP BETWEEN VIEWS, PERCEPTIONS AND PRODUCTION} IN HELSINKI SWEDISH

Sarah Wikner, Åbo Akademi University/The Society of Swedish Literature in Finland

This article deals with the relationship between people's views, perceptions and production regarding two language features in Helsinki Swedish. The features in focus are consonant lengthening in stressed V:C syllables (e.g. [ba:k:a], 'to bake') and vowel lengthening in combination with dropping of final $-r$ in verbs in present tense and plural nouns (e.g. [ta:la:], 'I speak'). The purpose of the study is to examine to what extent folkdialectological interviews can be applied to illuminate people's production of specific language features. The aim is also to study the variation of consonant lengthening in stressed V:C syllables and vowel lengthening in Helsinki Swedish and the relationship between people's views, perceptions and production regarding these features. For the study, 40 informants from Helsinki and its surroundings took part in an interview and a perception task.

The results show that people's views and perceptions corresponded to their production at an individual level, but only among those informants who mentioned the features in the interview or the perception task. However, approximately half of the informants did not mention the features at all, although some of them produced the features themselves. This means that there was no correlation between variation in production and whether or not the informants had mental representations of the features.

In general, the study points out the value of using different methods, investigating different aspects of language variation and relating them to each other in order to get a deeper understanding of the dynamics of language variation.

Keywords: consonant lengthening in stressed V:C syllables, dropping of final -r, folk linguistics, Helsinki Swedish, language variation, vowel lengthening 
